Gender

and

Language
G\&L (PRINT) ISSN: 1747-6321

G\&L (ONLINE) ISSN: 1747-633X

Theme Series

\title{
Thirty-year retrospective on language, gender and sexuality research Special focus: Politics
}

\author{
Edited by Kira Hall, Rodrigo Borba and Mie Hiramoto
}

\begin{abstract}
This thirty-year retrospective on language, gender and sexuality research, launched in anticipation of the thirtieth anniversary of the 1992 Berkeley Women and Language Conference, showcases essays by luminaries who presented papers at the conference as well as allied scholars who have taken the field in new directions. Revitalising a tradition set out by the First Berkeley Women and Language Conference in 1985, the four biennial Berkeley conferences held in the 1990s led to the establishment of the International Gender and Language Association and subsequently of the journal Gender and Language, contributing to the field's institutionalisation and its current pan-global character. Retrospective essays addressing the themes of Politics, Practice, Intersectionality and Place will be published across four issues of the journal in 2021. In this inaugural issue on politics, Robin Lakoff, Susan Gal and Alice Freed analyse the current political scenario from their feminist linguistic lenses, while Sally McConnell-Ginet and Norma Mendoza-Denton share more personal views of the politics involved in doing research on language, gender and sexuality. The theme series also pays tribute to significant scholars present at the 1992 Berkeley conference who are no longer with us; in this issue, Amy Kyratzis pays homage to the groundbreaking work of Susan Ervin-Tripp.
\end{abstract}

